\title{
Myanmar-China peculiar relationship: Trade, investment and the model of development
}

\author{
Andrzej Bolesta \\ United Nations Economic and Social Commission for Asia and the \\ Pacific, Bangkok \\ Thailand \\ andrzejbolesta@hotmail.com
}

Abstract. Myanmar and China have a long tradition of bilateral economic relations, the intensity of which has been changing according to political circumstances. In the late 1980s bilateral trade growth accelerated, and so did China's investment volume in Myanmar. Although economic and political liberalisation of Myanmar has resulted in a slowing down of bilateral trade and investment dynamics due to the growing number of international economic partners, China remains one of the most important among them. Although the topic of trade and investment between Myanmar and China is relatively well covered in various studies, most of the analyses omit an additional peculiar relationship. Both countries are postsocialist economies. Today they are at different stages of economic transition and development, still, they have followed similar developmental trajectories. This is because post-socialist Myanmar has emulated China's model of socioeconomic development. The China's model is based on the concept of Post-Socialist Developmental State, a fusion of the historical developmental state concept and post-socialist systemic transformation. The imitation of this Chinese model is demonstrated by the content of Myanmar's industrial policy, trade and investment policy and the arrangements concerning the financial system. Myanmar's policy makers have targeted a vast array of industrial sectors for development, relied on the companies affiliated with the regime, opened up gradually and selectively for international trade, attracted foreign investments by establishing special zones and kept the financial sector closed.

Keywords: China, Myanmar, Post-Socialist Development.

JEL Classification: O10, O20, E60

* "The views expressed herein are those of the author and do not necessarily reflect the views of the United Nations" 


\section{INTRODUCTION}

Due to their geographic proximity and historic factors such as China's expansionist tendencies, Myanmar and China have a long tradition of interaction. Inevitably, this was partly related to economic relations. In particular, the recent emergence of China as an economic superpower and Myanmar's dynamic socioeconomic development in the recent decades, as well as some political factors, have given these two countries additional reasons for expanding trade and investment. Today, China is the biggest investor in Myanmar and also its biggest trading partner. China's strong economic clout in Myanmar will most probably continue in the foreseeable future, despite the latter diversifying its portfolio of economic partners.

Although growing economic cooperation between two neighbouring states, particularly those that are fast developers in the times of globalisation, may not be seen as an unexpected phenomenon, the MyanmarChina relationship in the recent decades has gone beyond the mode of simply economic and political interaction; it has also concerned the model of development. Both economies have been undergoing postsocialist economic transformation and Myanmar, in the years 1988-2015, chose to emulate the Chinese model of development, with its closed political system, limited economic liberalisation, state interventionism and heavy regulatory regime, as well as with its industrial policy.

This article examines the peculiar economic relationship between Myanmar and China, explaining their trade and investment cooperation and illustrating how Myanmar has adopted China's model of development.

The article begins with the examination of Myanmar-China economic relations. It then proceeds to analyse China's development model. Part three focuses on presenting similarities between Myanmar and Chinese development models in such spheres as industrial policy, trade and investment policies and also financial sector policies.

\section{MYANMAR-CHINA ECONOMIC RELATIONS: THE TRADITIONAL PERSPECTIVE}

China-Burma/Myanmar's political and economic interaction has a long history dating back to the beginning of the last millennium and the invasion by the Mongol Yuan dynasty in the thirteenth century, which at that time ruled China. Burma (the official name was changed to Myanmar in 1989) was the first non-communist country to recognise the Chinese communist regime in 1949 and thus the People's Republic of China (PRC). This took place out of fear of possible invasion from the Chinese communist forces (Lee et al., 2009), which could have been prompted by the presence of the Kuomintang (or Chinese nationalist) troops in the border areas (Taylor, 2015). As the leader of the Republic of China Chang Kai-Shek lost the civil war to Mao Zedong and the communists, some of his troops crossed border with Burma at the Yunnan province and settled in the mountainous Shan and Kachin states, later relocating to Laos (at that time not controlled by the communists) and also to Thailand.

The time, during which the office of Burma's prime minister was held by $\mathrm{U} \mathrm{Nu}$ (1948-1962, except for 1956-1957 and 1958-1960) was described as an "ambivalent peaceful coexistence" (Shee, 2002, p. 34), during which Burma did not engage in international cooperation which was viewed by Beijing as threatening, such as the Manila pact (1950) and the SEATO (Southeast Asia Treaty Organization) establishment, a defence pact against the encroaching communism in the region. During the Ne Win regime (1962-1988) the paukphaw (cousinly) relations were tamed and bilateral trade banned (Shee, 2002, p. 42). Ne Win's pro-Soviet sympathies and the anti-Chinese riots in Yangon in 1967, as well as the 1968 de facto Chinese invasion of northern Burma contributed to the significant cooling down of bilateral relations. However, in the late 1970s relations began to warm up; in 1978 Deng Xiaoping visited Yangon and in 1985 Ne Win was received in Beijing. In the meantime, China reduced its assistance to the Burmese Communist party (which opposed 
the government in Yangon), which earlier committed the strategic mistake of supporting a Maoist course and the Gang of Four in China after the death of PRC's chairman.

The economic liberalisation in Myanmar after 1988 brought new economic cooperation opportunities. However, the year 1988 was also marked by the first set of international sanctions (after the pacification of the so-called 8888 uprising), which would then be regularly re-imposed by the Western world on Myanmar for its leadership's human rights violations. Thus, the mixture of political and economic factors led Myanmar to tighten its economic relations with China. It is believed that it was predominantly China who looked for closer bilateral engagement, due to three main reasons:

- Firstly, Myanmar is a neighbouring country. It is always beneficial to have a friendly neighbour, and preferably a dependent one enticed by a web of economic interconnectedness;

- Secondly, Myanmar has significant deposits of energy and other natural resources and China needs them to fuel its growth;

- Thirdly and most importantly, Myanmar is a key country as far as transit to China of energy and natural resources from Africa and the Middle East is concerned, and also, in the long term, in relation to China's consumer goods' export to Europe, the Middle East and Africa. Transit through Myanmar makes the journey shorter and allows for the avoidance of the potentially politically unstable and heavily contested waters of the Malacca Strait and South China Sea.

China, thus, gladly filled the economic and political space created by Myanmar's growing economy and international political ostracism.

The leader of the new junta Than Shwe (as Vice-chairman of the State Law and Order Restoration Council) visited Beijing in October 1989. A military delegation secured an arms deal worth around 1.4 billion USD. In December 1989 both sides signed an economic and technical cooperation agreement. Loans and grants started to flow from Beijing. A number of Chinese investment projects in Myanmar were initiated, in particular in the 2000s. Anecdotic evidence suggests that China has been involved in around 90 different energy projects in Myanmar, including the planned or on-going construction of at least 10 dams. The most publicised project has been the 3.6 billion USD Myitsone dam, the largest ( $6 \mathrm{GW}$ ) out of seven dams to be built on the Mali, the N'Mai and the Irrawaddy rivers. The dams are intended to generate jointly $20 \mathrm{GW}$ of hydro-energy. The construction of Myitsone dam was suspended by president Thein Sein in 2011 citing social and environmental concerns. However, in August 2016 a new commission was formed by president Htin Kyaw to decide the future of the project and in November 2016 a preliminary report was drafted. Moreover, the gas and oil pipelines from the Bay of Bengal to Kunming (the capital of the Chinese Yunnan province) - the projects, in which the China National Petroleum Corporation is a majority shareholder are already both operational. China has also had vested interests in the mining sector in frontier areas, Letpadaung copper mine being the most well-known example, due to it being subject to a parliamentary commission investigation chaired by the National League for Democracy (NLD) leader Aung San Suu Kyi in 2013.

PWC (2016) estimated the aggregate value of Chinese investment in Myanmar at 18.4 billion USD (31 percent of all foreign investments). Some investments have been rerouted through Hong Kong, and hence the special administrative region has been responsible for 7.5 billion USD worth of FDIs (foreign direct investments) (12.5 percent). Most of the investment has been continuously directed at the energy and natural resources sectors, as indicated earlier. However, recent data indicate that the investment portfolio is being gradually diversified into real estate, banking and others. For example, China Three Gorges Corporation partnered with the Ministry of Electric Power of Myanmar to develop a wind farm (March 2016); the Myanmar parliament gave its go-ahead to China's conglomerate CITIC to hold an 85 percent stake in the Kyaukphyu oil and gas special economic zone (December 2015); Myanmar awarded a banking license to the Industrial and Commercial Bank of China (October 2014) (only a handful of international banks has 
this right); and in June 2016, the Ministry of Construction awarded a bid to China Road and Bridge Co. Ltd to build two sections of roads as part of the Greater Mekong Subregion.

At the same time, bilateral trade has grown rapidly. According to ADB (2016) data, continuously since 2001 China has been the leading source of Myanmar's import. It reached 3.04 billion USD in 2015 (then fell to 2.69 billion in 2016) and constituted 28 percent of all Myanmar's imports. Once the gas and oil pipelines became operational, China became the main export destination in 2014 and the value of export reached 7.72 billion USD (43 percent of all Myanmar's export). Nevertheless, in the years 2015 and 2016 Thailand regained its top position as export destination, as export to China fell to 2.57 billion USD and 2.09 billion USD respectively; a clear sign of China's economic slowdown and the working of integrational forces within the ASEAN Economic Community (AEC). Despite this, in March 2016 'an agreement between PetroChina and the Myanmar government was signed that would allow the Chinese energy company to import oil via the Bay of Bengal and pump it through a pipeline to supply a 260,000-barrel-per-day refinery in Yunnan province' (PWC, 2016, p. 13). This should be seen as a component of the process of increased efficiency in management of the bilateral economic relations, perhaps intended by the Chinese side as part of policy to alleviate the risks of slowing down dynamics.

What gave the bilateral trade the necessary boost in the late 1980s was the trans-border trade. Myanmar, until then an isolated "hermit kingdom", lacked a number of low-end goods, produced in plenitude in China. Myanmar, thus, became a market for Chinese consumer goods such as bicycles, sewing machines, cheap textiles, radios, medicines and refined petrol (Hilton, 2013). It would export timber and gems, legally and illegally. Narcotics would become one of the main traded illegal merchandise. In 1988 the first border trade agreement was signed between Myanmar Export and Import Services and Yunnan Machinery Import Export Corporation. The government agreement on border trade followed in 1994.

There are contradicting views about the character of the bilateral economic relations between Myanmar and China, although most of the commentators agree that it was very intensive in the years 1988-2011. Kudo (2006) points out that this relation was lopsided, as Myanmar developed a high trade deficit, not to mention, greatly unfavourable terms of trade, which contributed to the Myanmar political leadership's dependence on China. However, Lee et al. claim that 'the junta $[\ldots]$ skilfully played the China card to improve or maintain good relations with the ASEAN [...], especially Thailand [as well as] India and Japan' (Lee et al., 2009, p. 106). In effect, a "constructive engagement" with ASEAN led to Myanmar's accession to the Association in 1997.

However, it is believed that the dynamics of political reforms commenced in 2011 in Myanmar caught China off guard. 'Political transition [...] complicated a previously cosy arrangement between two authoritarian governments' (Hilton, 2013, p. 1). Although in 2011 the two countries signed a "comprehensive strategic cooperation partnership", 'elevating bilateral relations and expanding exchanges and cooperation at all levels, strengthening mutual strategic support, deepening pragmatic cooperation, and maintaining border stability' (Sun, 2012, p. 80), the economic implications of the political transition resulted in the de-acceleration of economic interaction in the investment area, partly illustrated by stalled or cancelled investment projects, including the flagship energy project, namely, the construction of Myitsone dam.

The political disengagement intensified negative sentiments within Myanmar's society towards Chinese business. 'Hostility to China at all levels of society and unresolved ethnic tensions in Myanmar have focused popular anger on Chinese investments, seen as symbols of the continuing power of Myanmar's military and its crony business partners' (Hilton, 2013, p.1). According to a study cited by Christie and Hanlon (2014) there has been 'deep distrust towards China's State-Owned-Enterprises (SOE). Many felt that Chinese FDI did not benefit the average Burmese citizen. Instead, they helped a small group of elite officials and the management of the SOE' (Christie \& Hanlon, 2014 p. 7). Therefore Kulczuga (2013) rightly notes that 'one problem China faces is that while it has poured billions of dollars into investment projects in [Myanmar] it 
has failed to maximize on [...] soft power. The Chinese bring their own labourers and resources, and don't use local companies. Because they keep themselves isolated from the local culture, they fail to provide many of the ancillary benefits host nations have come to expect from foreign developers' (Kulczuga (2013 p. 37).

Nevertheless, it is plausible to claim that accounting for a significant share of Myanmar's international trade (22 percent) and a significant share of foreign investments, China has been the country of most influence on Myanmar's development. Due to economic, geographic and other reasons China's weight in Myanmar will continue to be extensive, despite the already visible process of it slowly diminishing.

There is, however, a very different element of the China-Myanmar relationship, namely one which does not relate to trade and investment, but nevertheless has immense economic clout. It is broadly believed that Myanmar adopted China's development model in its period of systemic transformation from socialism between 1988 and 2015, as the military junta under general Than Shwe (1992-2011) hoped to emulate the Chinese model of development and transformation (Lubina, 2014), in which economic reforms allowed for a significant increase in wealth (mostly for those in charge of the reforms and of the country) and the power remained in the hands of the ruling party. The process of emulation intensified under president Thein Sein during the acceleration of economic reforms (2011-2015).

\section{CHINA'S MODEL OF DEVELOPMENT}

China's model of development is based on the provisions of the post-socialist developmental state. Coined in the early 2000s, the concept has subsequently been developed into a concrete construction, containing features related to state ideology, systemic arrangements and economic policies (Bolesta, 2015).

The concept of post-socialist developmental state (PSDS) fuses two intellectual streams, that of the developmental state (DS) and that of the post-socialist transformation (PST).

As far as the DS concept is concerned (see: Amsden, 1989; Johnson, 1982; Wade, 1990; Cumings, 1984), '[it] is widely believed to be the conceptual background of state policies and state institutional arrangements, leading to the unprecedented developmental achievements among the so-called late developers of the Asian continent' (Bolesta, 2015, p. 7). Despite its critics (see: Woo, 2011; Page, 1994; World Bank, 1993), it is beyond doubt that the ascendance of Japan, Korea and Taiwan, all three countries and territories having been developmental states, into the group of highly developed nations has been the fastest in the world's recent economic history (Jacques, 2012).

In the DS concept, the state's main ideology is nationalism (Johnson, 1982) and, in particular, economic nationalism, which constitutes the background for economic policies and protectionist measures to shield the domestic economy from unwanted penetration by foreign economic entities and, in particular, to create somewhat a cocoon for the domestic business sector to mature. This has the effect, where deemed necessary, of sectoral deterrence of foreign businesses and of the legal favouring of domestic companies.

The state economic policies are framed within the process of industrialisation, and more precisely, import-substitution industrialisation (ISI), which is followed by export-oriented industrialisation (EOI) (Haggard, 1990; Jeon, 1995; Stubbs, 2009). Those policies are determined by the wild geese flying pattern (Akamatsu, 1962) and by the concept of "industrialising by learning and then by innovating" (Amsden, 1989). They employ state targeting as the main mechanism to develop particular industrial sectors. This targeting is characterised by the gradual increase of value-added production. In the case of contemporary post-socialist developmental states, export orientated production is facilitated by special economic zones (SEZs). Industrial policy is supported by trade policies to selectively discriminate import and selectively support export and through a broad array of financial sector-related policies, including subsidies, manipulation of interest and exchange rates and the subordination of the banking sector to the developmental necessities. Access to the banking sector is heavily guarded and limited for foreign entities, 
according to the principles of economic nationalism. Investment policy is selective and heavily regulated, leaving little space to manoeuvre for foreign investors and for independent activities.

Despite the fact that the post-socialist transformation's partial incentive was the need to accelerate socio-economic development and the DS model proved to have been the most successful policy and institutional arrangement in the second half of the twentieth century in this respect, attempts to combine those two intellectual streams have been scarce. This is because the DS model has often been seen as a historical phenomenon with little meaning in the era of globalisation and, at least in theory, the two processes have not occurred concurrently, as the PST coincided with the elevation of neo-liberalism to the only acceptable paramount economic ideology.

The task of the PSDS is significantly broader than that of DS. In addition to guiding development trajectory, the post-socialist developmental state must also be responsible for post-socialist systemic transformation, namely economic liberalisation, market institutionalisation and microeconomic restructuring. This economic-systemic reorganisation creates unfavourable conditions; the state focuses on systemic reformulation and usually neglects the developmental necessities, as was the case in a number of countries in Central and Eastern Europe (partly due to ideological reasons) and the economy is entangled in the "transitional vulnerability" due to an institutional and legal vacuum, which limits the state's developmental abilities. From a systemic and institutional perspective, and in order to perform the aforementioned tasks, the conditionality of the PSDS requires that the state remains at the centre of the process of transformation and development and its retraction from the national economy is more limited than was the case in a number of countries in post-socialist transition.

\section{MYANMAR AND CHINA: THE SIMILARITIES OF THE MODELS OF DEVELOPMENT}

China and Myanmar are both post-socialist economies, which have been undergoing systemic transformation. In Myanmar (then called Burma), the main transformation towards the state-command and centrally-planned socialist economy took place after the 1962 coup d'état. Under "military socialism" general Ne Win nationalised 15 thousand private firms and established a massive public sector represented by state corporations called SEES (State Economic Enterprises) (Aung-Thwin et al., 1992). In China, a socialist People's Republic was established in 1949 after a civil war between the Nationalists (Kuomintang) and the Communists. As a result of a number of systemic reforms and transformational policies, China's economy became a fully-fledged socialist economy by 1956 (OECD, 2009). In Myanmar, the post-socialist transformation commenced in 1988, after another coup d'état. In China, the systemic reforms were initiated by Deng Xiaoping in 1978, after the death of Mao Zedong.

It is sometimes argued that, in the case of Myanmar, the years 1988-2011 constitute the first phase of the post-socialist systemic transformation. However, according to a UNESCAP (2015) report the reforms had been implemented only until 1996 and the next 15 years were characterised by abandonment and even regress in the reform efforts, which was the result of both internal conditions (the military junta was afraid that economic liberalisation would lead to its losing of political control) and external conditions (the Asian financial crisis of 1997; sanctions imposed on Myanmar by Western governments). From that period comes important legislature, which facilitated the process of the creation of a market system, namely:

- Foreign Investment Law (1988);

- State-owned Economic Enterprises Law (1989);

- Private Industrial Enterprises Law (1990);

- Financial Institutions Law (1990);

- Promotion of Cottage Industries Law (1991); 
- Cooperative Society Law (1992);

- Mines Law (1994);

- Myanmar Citizens’ Investment Law (1994);

- Accountancy Council Law (1994).

The subsequent period of reform (2011-2015) was characterised by the proliferation of different plans for socio-economic development and transformation (see: Myint, 2013). A dynamic acceleration of transformation, in the form of economic liberalisation, market institutionalisation and microeconomic restructuring, presided over by the quasi-civilian government of general Thein Sein was possible due to the implementation of a number of legal regulations paramount for the functioning of a market economy (see table 1).

Table 1

Regulations related to macroeconomic liberalisation, market institutionalisation and microeconomic restructuring

\begin{tabular}{|c|c|c|}
\hline & Law & Year of implementation \\
\hline 1 & Myanmar Special Economic Zone Law & 2011 \\
\hline 2 & Dawei Special Economic Zone Law & 2011 \\
\hline 3 & Microfinance Law & 2011 \\
\hline 4 & Trade Union Law & 2011 \\
\hline 5 & Foreign Exchange Management Law & 2012 \\
\hline 6 & Myanmar Foreign Investment Law (MFIL) & 2012 \\
\hline 7 & Environmental Conservation Law & 2012 \\
\hline 8 & The Farm Land Law & 2012 \\
\hline 9 & Vacant, Fallow and Virgin Land Law & 2012 \\
\hline 10 & The Export and Import Law & 2012 \\
\hline 11 & The Settlement of Labour Dispute Law & 2012 \\
\hline 12 & The Employment and Skill Development Law & 2012 \\
\hline 13 & Exchange rate liberalisation & 2013 \\
\hline 14 & Anti-Corruption Law & 2013 \\
\hline 15 & Central Bank of Myanmar Law & 2013 \\
\hline 16 & Telecommunication Law & 2013 \\
\hline 17 & Myanmar Citizens Investment Law (MCIL) & 2013 \\
\hline 18 & Minimum Wage Law & 2013 \\
\hline 19 & Anti-Money Laundering Law & 2014 \\
\hline 20 & The Special Economic Zone Law & 2014 \\
\hline 21 & Foreign exchange management regulations & 2014 \\
\hline 22 & Securities Exchange Law & 2014 \\
\hline 23 & Union Tax Law & 2015 \\
\hline 24 & The Competition Law & 2015 \\
\hline 25 & Small and Medium Enterprise Development Law & 2015 \\
\hline
\end{tabular}

Source: Compiled by the author.

In China, up until 1984 systemic reforms were mainly contained to the rural areas and focused on abandoning the commune system and creating a market for agricultural products by partial price liberalisation. The first decade of transformation was characterised by attempts at creating a market socialist system (see: Huang, 2008), thus followed a path of limited liberalisation. The acceleration of marketisation 
began in the early 1990s and was related to China's WTO accession. Consequently, this was the period when most market regulations were introduced. The Hu-Wen administration (2003-2013) tried unsuccessfully to avert social and environmental costs of the transformation - the growing inequalities and environmental degradation. The Xi Jinping era since has featured strengthening economic nationalism as a state ideology and the centralisation of the decision-making process on economic policies.

However, there are significant similarities in the post-socialist development models between China and Myanmar. It is due to the fact that Myanmar has adopted various Chinese solutions in reference to the sectoral development policies, as examined below.

\section{Industrial Policy}

Industrial policy understood as coordinated activities by the state for the development of selected industries (see: Chang, 1999; 2009; Cimoli et al., 2008; Rodrik, 2007; ul-Haque, 2007), has usually been an element of the economic policy of independent Burma/Myanmar, despite the lack of adequate results. Its present form seems largely to imitate the Chinese model. Although it does not exhibit the structuralist import-substitution industrialisation (ISI) (see: Prebisch, 1950) characteristic of Latin America (considered the first developing region to industrialise) (Kong, 2000), it shows inclination towards the East Asian style export-orientation industrialisation (EOI).

The Chinese model, despite the fact that it recognizes the need to increase the technological advancement of industrial production, is based on a parallel growth of as many industries as possible. This preference for broad targeting is based on the conviction that the holistic development of such a large economy as China cannot rely on a few industrial sectors. Therefore, Chinese development strategies usually list a number of priority sectors, including agriculture, heavy machinery, electrical and electronic equipment, energy, clean-tech and advanced technologies (Kuchiki, 2007).

Currently, Myanmar is favouring a similar approach and is implementing a model that is based on the internal advantages and the desire to take advantage of the fact that the country is joining the global economy as a late-comer, and thus can benefit from an easier transfer of technology, management and organisational techniques and other know-how. This meant that the government in 2011-2015 supported development of the agricultural sector (which employed between 60 and 70 percent of the workforce), as well as energy and mining, and various sectors of industrial production - from textiles to car parts (Myint, 2013). However, realizing insufficiencies in the quality of human capital (Burmese socialism did not bring about a relatively well-educated society, as was the case in many other socialist countries), the government has not treated advanced high-tech technologies as a priority sector at the current stage of development and modernisation.

In implementing the development strategy, the authorities have relied on both private companies and state-owned enterprises. Current estimates of the private sector and the public sector contribution to GDP vary considerably. The government claims that the private sector is responsible for 90 percent of GDP, the data of the IMF [International Monetary Fund] puts the figure at 85 percent, while other sources claim the share is 65-70 percent (BICS, 2015). The differences in estimates are due to the limited transparency within Myanmar's economy. Sometimes it is difficult to classify a particular company because of its many links and associations, including with the armed forces, whose business machinations are often shrouded in mystery.

It is worth noting the analogies between the "actors" of industrial policy in Myanmar and in China. In Myanmar, as in China, state economic enterprises (SEEs) can rely on preferential loans from state banks and government subsidies, and often do not have to care about financial discipline. Until April 2012, they were supported by a controlled foreign currency exchange rate, as did Chinese export-orientated producers through an undervalued RMB. According to the 1989 law, SEEs are guaranteed exclusive access to 12 industrial sectors; these are: '(a) extraction of teak and sale of the same in the country and abroad; (b) 
cultivation and conservation of forest plantation with the exception of village-owned firewood plantation cultivated by the villagers for their personal use; (c) exploration, extraction and sale of petroleum and natural gas and production of products of the same; (d) exploration and extraction of pearl, jade and precious stones and export of the same; (e) breeding and production of fish and prawn in fisheries which have been reserved for research by the Government; (f) post and telecommunications service; (g) air transport service and railway transport service; (h) banking service and insurance service; (i) broadcasting service and television service; (j) exploration and extraction of metals and export of the same; $(\mathrm{k})$ electricity generating services other than those permitted by law to private and cooperative electricity generating services; (l) manufacture of products relating to security and defense' (BICS, 2015; Rieffel, 2015). Despite the fact that SEEs have been gradually losing their monopoly, they continue to play prominent sectoral roles, as is the case in the mining and oil and gas sectors of Myanma Oil and Gas Enterprise, Myanma Petrochemical Enterprise, Myanma Petroleum Products Enterprise, Mining Enterprise 1, 2 and 3. In the case of China, these sectors are also dominated by large state-owned companies, which include, among others, Sinopec, PetroChina and Shenhua group. This is almost an exact copy of the Chinese catalogue, which clearly delineates which industrial sectors are reserved for state-owned domestic enterprises and which are not (Breslin, 2006).

In addition, 14 state governments and regional and municipal authorities of large cities established separate companies, operating in local markets (Rieffel, 2015), to a large extent similar to the Chinese TVEs (town and village enterprises). TVEs were the product of vague ownership regulations on the one hand, and the desire of local political elites to harness the profits from the marketisation of the national economy on the other. They played an important role in the economic transformation, especially in the context of providing employment for the inhabitants of rural areas previously employed in agriculture.

Nevertheless, the role of Myanmar's SEEs will not continue to be as prominent as in the case of stateowned enterprises (SOEs) in China. This assertion does not rely exclusively on the data concerning GDP, which is generated mostly by private companies. Rather it is based on the fact that the political elite associated with the armed forces and previous governments appropriated through shady privatisation machinations large shares of state-owned assets. Consequently, it is in their interest to continue to secure public contracts and subsidies for their "private" companies and thus maintain an important position as the actors of industrial policy. It is a similar situation to that of China, in which rampant corruption is sustained by cooperation between local authorities and private companies, whose owners are often former ranks of government (Ding, 2000).

\section{Trade and Investment Policy}

As far as the EOI is concerned, the Myanmar government has intended for its country to benefit from its geographic location as well as manpower resources, and to make Myanmar at least a regional factory if not a global factory in some labour-intensive sectors (China has become a global factory). However, this remains to be a strategy. According to an OECD (2016) report Myanmar mainly exports gas (24 percent), textiles $(7$ percent) and vegetables ( 6 percent). The total value of merchandise export in 2016 was 11.7 billion USD (World Integrated Trade Solution, 2016). Official statistics do not include illegal trade, which is dominated by timber and precious stones (primarily jade and rubies), and which is mostly carried out across the border with China.

Despite the liberalisation of international trade, many restrictions are prevalent, as has been the case of China. In Myanmar, import and export is, to a large extent, reserved for local companies. A company requires a certificate confirming its status as an importer and/or exporter and this certificate is normally not produced to foreign entities. The Ministry of Commerce ceased to renew import/export certificates to foreign firms in 2001 and 2002 (Luther, 2016). Moreover, for many goods, companies are required to obtain 
an additional license from the Ministry of Commerce to import or export. Nevertheless, the Ministry has gradually increased the number of goods which do not need a license. In 2013318 types of goods did not require a license; in 2014 an additional 152 were added to the list. Foreign companies have a right to apply for an import license for the purpose of their own production. They cannot, however, conduct trade, therefore, cannot obtain a license for export. This does not apply to firms located in special economic zones, in which regulations are more relaxed.

China has had a long tradition of limiting access to its market, rather than prohibiting foreign companies to trade. The instruments include laws, regulations and policies, sectoral activities as well as adhoc actions (Bolesta, 2015) and are usually examined in detail by the reports of the European Union Chamber of Commerce in China. In effect both sets of policies, those of Myanmar and those of China, limit trade opportunities for foreign firms.

However, the creation of special economic zones (SEZ), as was the case of China, is an important factor in the development of Myanmar's industrial base and subsequently export-oriented production, with the participation of foreign capital and foreign technology. In Myanmar there are currently three SEZs: Thilawa - a zone established in 2013 and located near Yangon, with an area of 2.4 thousand hectares, dominated by Japanese companies; Dawei - a zone in the south of the country, built by a consortium of Italian-Thai firms and supported by Japanese companies, whose location is best suited for the needs of the Bangkok market; and Kyaukphyu in Rakhine state - a zone with twelve registered companies, including eleven from China, created in the vicinity of the oil and gas pipeline to China. The government plans to create new zones - Pathein and Myawaddy. In addition, the authorities have established 18 industrial parks in the following regions: Ayeyarwady (3), Bago (1), Magway (2), Mandalay (3), Mon State (1), Sagaing (2), Shan State (1), Tanintharyi (1), Yangon and surrounding areas (4). Despite their limited use - only 20 percent of the area of industrial parks is used, the government plans to open an additional ten units: in the Bago region (1), Chin state (1) Kayin state (1), Mandalay area (3), Mon state (1), Rakhine state (1), Shan state (1), and Tanintharyi (1).

The variety of special areas aimed at attracting foreign investment for the purpose of export production is a copy of the Chinese model. Special arrangements were created for special economic zones (SEZ) in Shenzhen, Zhuhai, Shantou and Xiamen (1979-80), as well as Hainan (1988), open coastal cities of Dalian, Qinhuangdao, Tianjin, Yantai, Qingdao, Lianyungang, Nantong, Shanghai, Ningbo, Wenzhou, Fuzhou, Guangzhou, Zhanjiang and Beihai (1984), open zones in the Yangze river delta and the Zhujiang (Pearl) river delta, the triangle of the Southern Fujian, the Liaodong and Shandong peninsulas, Hebei and Guangxi provinces (1985), the Shanghai-Pudong zone (1990), open ports of the Yangtze river - Chongqing, Yueyang, Wuhan, Huangshi, Jiujiang and Wuhu, as well as the thirteen open border cities - Yining, Bole, Tacheng, Erenhot, Manzhouli, Heihe, Suifenhe, Hunchun, Ruili, Wanding, Hekou, Pingxiang and Dongxing. In addition, fifty-four economic and technological development zones (ETDZ), fifty-three high-tech industry development zones (HIDZ), as well as sixty export processing zones and fifteen bonded zones have been created in various parts of the country (Alder et al., 2013). In 2013, the government established the Shanghai Free Trade Zone, and in 2015 similar zones were created in Tianjin and the provinces of Fujian and Guangdong.

Up until now, the main incentive for foreign investors in Myanmar were natural resources, and, to a lesser extent, a fast growing and non-saturated consumer market of 53 million people. Tax holidays and tax exemptions have been offset by non-tariff barriers, corruption and bureaucratic procedures, thus making them relatively unimportant for investors.

In China, restrictions concerning foreign investment took the form of a catalogue. 'From 1995, this differential approach to foreign investment was formalised in "The Catalogue Guiding Investment in Industry" [or the Foreign Investment Catalogue], which, on an industry-by-industry basis, shows where 
investment is prohibited, restricted, encouraged or permitted - prohibited (e.g. essential services, defence sector, heavy pollutant product industries and those illegal under Chinese law), encouraged (exportorientated, high-tech and pro-forma those who could not be restricted under the WTO regulations), and restricted (those deemed to be central to national economic development such as certain foods, medical products, raw materials, power plants, chemical, etc.)' (Breslin, 2006, p. 21).

However, in contrast to the Chinese model, Myanmar's catalogue focuses largely on sectors reserved for the state. Nevertheless, the law leaves some discretion for the Myanmar Investment Commission (MIC) to allow exemptions for private Myanmar companies and, in exceptional situations where it is necessary to obtain know-how, for foreign firms. According to the Burma Investment Climate Statement produced by the US State Department, foreign companies cannot invest in a number of sectors related to culture, religion, tradition, as well as forestry, small scale mining and energy, railways and some services. The 1989 investment law stipulates that SEEs have the sole right to carry out the economic activities in a number of sectors mentioned earlier, which effectively bars foreign investors. The OECD report cited in the Burma Investment Climate Statement states that the law on foreign investment 'still leaves many questions unanswered, notably with respect to investor protection and the procedures for admitting foreign investors' (BICS, 2015). The state's institutional and capacity limitations result in the main responsibility for foreign investment being transferred to the MIC, without, however, effective support of the law. MIC thus plays a major role in the investment process outside the special economic zones, as it approves investment projects following the provisions of the foreign investment law. It often uses its discretionary powers. Moreover, it has the right to create additional regulations on the basis of the existing law. Currently, MIC seems to use them to restrict access to the market. It has eliminated tax incentives in certain sectors. In the Notification $51 / 2014$ it eliminated the customs privileges and exemptions for companies investing in the production of alcohol and tobacco products, the sale of oil and gas, exploration of natural resources, hiring vehicles and machinery and limited the incentives in the sector of milk production. Moreover, new environmental regulations require an investment assessment in such sectors as oil and gas production, construction and all large investments. Although it may not sound unusual and perhaps should be applauded as a welcoming policy towards the natural environment and the limiting use of tobacco and alcohol, considering Myanmar's rampant corruption (in the 2016 ranking it held 136 th position among 176 countries examined by Transparency International), the environmental policy makes investment more difficult rather than aids environment, as the assessment reports and issued permissions are often determined through an exchange of bribes. Another investment obstacle derives from the law concerning land ownership. Foreign firms are usually barred from owning land, though they can sign relatively long lease contracts. Another deterrent concerns labour regulations. Local workers must constitute 25 percent of a foreign company's work force during the first two years of activity, 50 percent in the next two, and 75 percent in the next two. With the limited quality of the local labour force and persistent deficiencies in skilled labour, such policies discourage foreign investors recruited from the group of small and medium-sized businesses who do not have the resources to conduct training programs.

The policy of limiting business opportunities for foreign entities is perhaps not so expressive and sophisticated as in the case of China. Nevertheless, the observed trend, in particular in the years 2014 and 2015, seems towards creating more obstacles for foreign companies and preserving sectoral opportunities for domestic firms.

\section{The Financial Sector Policies}

The financial sector is a good example illustrating the attachment of Myanmar to China's model of development. The Myanmar financial sector comprises: Central Bank, the Ministry of Planning and Finance 
(formerly the Ministry of National Planning and Economic Development and the Ministry of Finance (and Revenue)), state-owned banks, private banks and other financial firms, representative offices of foreign banks. In the socialist period (1962-88) private banks were nationalised. In the 1990s the government allowed for limited operations of newly established private banks. The banking crisis of 2003, however, discouraged further development of the banking sector. A report by GIZ [Gesellschaft fur Internationale Zusammenarbeit] in 2015 concluded that since 2011 the financial system has been undergoing "far-ranging reform", as a result of which: private banks began conducting currency exchange (since 2011); the liberalisation of the exchange rate of the local currency (kyatt) took place (2012); and legal independence of the Central Bank from the Ministry of Finance was created (2013) (Foerch et al., 2015).

Currently there are four main state banks operating in Myanmar, whose activities are similar to the socalled policy banks in China. Myanmar Foreign Trade Bank specialises in international banking, as did the Bank of China. Myanmar Agriculture and Development Bank is involved in transactions related to the agricultural sector, which was the domain of the Agricultural Bank of China. Myanmar Economic Bank and Myanmar Investment and Commercial Bank support the activities of the country, except that MICB can conduct international transactions. Their portfolio corresponds, to a large extent, with those of China Construction Bank and the Industrial and Commercial Bank of China. There are 12 fully private banks (owned by local capital) and 12 private banks with partial state ownership operating on the market. In 2014 the Central Bank awarded licenses to nine foreign banks, and in 2015 to an additional four foreign banks. Upon fulfilling the high capitalisation requirement of around 75 million USD, they were permitted to provide a very limited scope of services. China applied a similar policy in the mid-2000s. After meeting the $100 \mathrm{mln}$ USD capitalisation requirements, foreign banks were excluded from most financial services and lucrative government projects (Bolesta, 2015).

The development of the Myanmar banking sector lags behind the advancements of the entire national economy. The same can be said about China. In Myanmar, the sector is still strongly regulated and controlled by the state; the range of services is very limited, and despite the lifting of international sanctions concerning financial services, international credit cards were only introduced in 2016. As a result, an informal sector has played an important role, similar to that of rural credit cooperatives in China in the 1980s (see: Huang, 2008).

Nevertheless, the financial sector recorded some successes in its development trajectory. An increasing number of citizens use banking services (in 2010 only around 10 percent of the population had bank accounts). In December 2015 a stock exchange was opened in Yangon; the first company - First Myanmar Investment - was listed in March 2016. Stock exchanges were an important part of the process of marketisation of the Chinese economy. In 1990 they were established in Shanghai and Shenzhen.

\section{CONCLUSION}

The economic interaction between Myanmar and China has a long history, which is the result of geographic proximity as well as geo-political positioning. In the long term, China has been Myanmar's main trading partner and its main investor. Despite general Thein Sein's government's attempts to diversify international trade routes and foreign investment sources, China, the second largest economy and a global superpower, will remain an important economic partner.

Scholarly analyses often omit that both countries share more than a history of economic and political interactions. They are both post-socialist economies, which have been undergoing the process of transformation from state-command, centrally-planned economic models to market based systems; in other words, from a form of socialism to a genus of capitalism. China commenced its reforms in 1978 and then 
accelerated transformation in the 1990s. Myanmar commenced economic reforms in the late 1980s and then sped up in the 2010s.

This article has also argued that Myanmar copied China's model of post-socialist development. It has applied a multi-sectoral targeting in industrial policy, deterred and, at the same time, attracted foreign investors, using bureaucratic regulations and special economic zones, respectively. It has tightly controlled international trade and the banking sector. It has supported the domestic business sector, by creating uneven conditions to operate.

It is important to see the examination of Myanmar's industrial, trade and investment policies as well as Myanmar's financial sector not as a list of complaints. As mentioned above, the state's actions are framed within a relatively cohesive set of patterns, a model, which although in opposition to some general perceptions in favour of liberal economic doctrines, was earlier utilised by other countries. Although each state is different, post-socialist transformation allows us - to borrow a phrase from Timothy Garton Ash a use of a library of experiences (Garton Ash 2013), also with respect to development strategies. Myanmar's contemporary development trajectory is an amalgamation of intended strategies and prevailing chaos. Breslin (1996) argues that this was also the case of China. Both countries' development trajectories seem rooted in the concept of post-socialist developmental state with its limited economic liberalisation, interventionist state and favouring of local business.

\section{REFERENCES}

ADB [Asian Development Bank]. (2016). Key Indicators for Asia and the Pacific 2016 -Myanmar. Accessed, November 10, 2016, From: https://www.adb.org/sites/default/files/publication/204091/mya.pdf

Akamantsu, K. (1962). A Historical Pattern of Economic Growth in Developing Countries. Journal of Developing Economies, 1(1), 3-25.

Alder, S., Lin, Sh., \& Zilibotti, F. (2013). Economic Reforms and Industrial Policy in a Panel of Chinese Cities. Accessed February 23, 2015, From:

http://www.ubscenter.uzh.ch/assets/workingpapers/WP5_Economic_Reforms_and_Industrial_Policy_in_a_Panel of Chinese Cities.pdf.

Amsden, A.H. (1989). Asia's Next Giant: South Korea and Late Industrialization. Oxford, Oxford University Press.

Aung-Thwin, M., \& Thant, M-U. (1992). The Burmese Way to Socialism. Third World Quarterly, 13(1), 67-75.

Breslin, Sh. (2006). Foreign Direct Investment in the PRC: Preferences, Policies and Performance. Policy \& Society, 25(1), 9-38.

BICS (2015). Burma Investment Climate Statement. Washington, D.C.: US Department of State.

Bolesta, A. (2015). China and Post-Socialist Development. Bristol: Policy Press.

Chang, H-J. (2009). Industrial Policy: Can We Go Beyond an Unproductive Confrontation? A plenary paper for the Annual World Bank Conference on Development Economics, 22nd -24th June, Seoul.

Chang, H-J. (1999). Industrial Policy and East Asia - The Miracle, the Crisis, and the Future. A revised version of the paper presented at the World Bank workshop on Re-thinking East Asian Miracle, San Francisco.

Cimoli, M., Dosi, G., \& Stiglitz, J.E. (ed.). (2008). Industrial Policy and Development: The Political Economy of Capabilities Accumulation. Oxford: Oxford University Press.

Christie, K., \& Hanlon, R.J. (2014). Myanmar's China Threat: How the UN global Compact is changing development in Southeast Asia. Paper presented at the 11th Annual International Conference on Politics \& International Affairs and Annual International Forum on Policy and Decision Making, Athens, Greece.

Cumings, B. (1984). The Origins and Development of the Northeast Asian Political Economy. Industrial Sectors, Product Cycles and Political Consequences. International Organization, 38(1), 1-40.

Ding, X.L. (2000). The Illicit Asset Stripping of Chinese State Firms. The China Journal, 43, 1-28.

Foerch, T., Ki, O., Thein, S., \& Waldschmidt, S. (2015). Myanmar's Financial Sector: A Challenging Environment for Banks. Yangon: GIZ.

Garton Ash, T. (2013). Lecture at the invitation of the European Union Delegation, Yangon, February 2013.

Haggard, S. (1990). Pathways from the Periphery. Ithaca: Cornell University Press. 
Hilton, I. (2013). China in Myanmar: Implications for Future. NOREF Report, October.

Huang, Y. (2008). Capitalism with Chinese Characteristics: Entrepreneurship and the State. New York, NY: Cambridge University Press.

Jacques, M. (2012). When China Rules the World: The End of the Western World and the Birth of a New Global Order. 2nd Edition. New York: Penguin Books.

Jeon, J.G. (1995). Exploring the Three Varieties of East Asia’s State-Guided Development Model: Korea, Signapore, and Taiwan. Studies in Comparative International Development, 30(3), 70-88.

Johnson, Ch.A. (1982). MITI and the Japanese Miracle: The Growth of Industrial Policy, 1925-1975. Stanford: Stanford University Press.

Kong, T.Y. (2000). The Politics of Economic Reform in South Korea. A Fragile Miracle. London: Routledge.

Kuchiki, A. (2007). Industrial Policy in Asia. IDE Discussion Papers, 128. Chiba: Institute of Developing Economies.

Kudo, T. (2006). Myanmar's Economic Relations with China: Can China Support Myanmar Economy? Discussion Paper, 66, Chiba: Institute of Developing Economies.

Kulczuga, A. (2013). A Taste of Freedom: Burma's Guarded Optimism. World Affairs, March/April, 32-40.

Lee, P.K., Chan, G., \& Chan, L-H. (2009). China’s "Realpolitik" Engagement with Myanmar. China Security 5(1), 106.

Lubina, M. (2014). Birma: centrum kontra peryferie. Kwestia etniçna we wspótczesnej Birmie (1948-2013). Kraków: Krakowska Oficyna Wydawnicza Tekst.

Luther (2016). Trade Restrictions. Accessed: November 1, 2016. From: http://www.lutherservices.com/fileadmin/user upload/PDF/Broschueren/Geschaeftsaktivitaeten im Ausland/Myanmar/BanOn-Trade Myanmar.pdf

Myint, T. (2013). Economic Reforms in Myanmar - The Way Forward. In: Bolesta, A. (ed.). From Central Planning to Market: Poland's Transformation in a Comparative Perspective and the Lessons for Myanmar, 15-23. Bangkok: Chulalongkorn University.

OECD. (2016). Economic Outlook for Southeast Asia, China and India 2016: Enhancing Regional Ties. Paris: OECD Development Centre.

OECD. (2009). China. Defining the Boundary between the Market and the State, OECD Reviews of Regulatory Reform, Paris, OECD.

Page, J. (1994). The East Asian Miracle: Four Lessons for Development Policy. In: Fischer, S., Rotemberg, J.J. (ed.). NBER Macroeconomics Annual 9, 219-282, Boston: MIT Press.

Prebisch, R. (1950). Theoretical and Practical Problems of Economic Growth. Mexico City: United Nations. Economic Commission for Latin America.

PWC [PricewaterhouseCoopers]. (2016). Myanmar Business Guide, $4^{\text {th }}$ Edition, Yangon.

Rieffel, L. (2015). Policy Options for Improving the performance of the State Economic Enterprise Sector in Myanmar. ISEAS Working Papers, 1.

Rodrik, D. (2007). Normalizing Industrial Policy. Paper prepared for the Commission on Growth and Development.

Shee, P.K. (2002). The Political Economy of China-Myanmar Relations: Strategic and Economic Dimensions. Ritsumeikean Annual Review of International Studies 1, 33-53.

Stubbs, R. (2009). What Ever Happened to the East Asian Developmental State? The Unfolding Debate. The Pacific Review 22(1), 1-22.

Sun, Y. (2012). China and the Changing Myanmar. Journal of Current Southeast Asian Affairs 31(4), 51-77.

Taylor, R.H. (2015). General Ne Win: A Political Biography. Singapore: Institute of Southeast Asian Studies.

ul Haque, I. (2007). Rethinking Industrial Policy. Discussion Papers United Nations Conference on Trade and Development 183.

UNESCAP. (2015). Myanmar Business Survey: Data Analysis and Policy Implications. Bangkok: UNESCAP.

Wade, R. (1990). Governing the Market: Economic Theory and the Role of Government in East Asian Industrialization. Princeton: Princeton University Press.

Woo, W-T. (2011). The Changing Ingredients in Industrial Policy for Economic Growth. Paper presented at the Asia-Pacific Research and Training Network (ARTNeT) Symposium Towards a Return of Industrial Policy? 25-26 July, UNESCAP, Bangkok.

World Integrated Trade Solution. (2016). Accessed: October 31, 2016, From: https://wits.worldbank.org/CountryProfile/en/MMR

World Bank. (1993). The East Asian Miracle: Economic Growth and Public Policy. Washington, World Bank. 